\title{
The siLang Simulation Tool for Business Secondary Technical Education E.S.P. Students
}

\author{
http://dx.doi.org/10.3991/ijet.v11i04.5371 \\ Ch. Tsihouridis ${ }^{1}$, M. Batsila ${ }^{2}$ \\ ${ }^{1}$ University of Thessaly, Volos, Greece \\ ${ }^{2}$ Open University, Milton Keynes, United Kingdom
}

\begin{abstract}
The purpose of the paper is to detect Technical Secondary Education learners' views on the siLang software. Particularly the aim is to investigate its effectiveness on learners' reading and listening English language skills competence. A number of 64 learners and their four teachers participated in the research, conducted with quantitative and qualitative research methods. According to the results of students' questionnaire answers, focus group discussions and teachers' interviews the particular software is considered to be an authentic-like tool for business purposes, relevant to learners' future working needs, and capable of promoting learner motivation and participation in the lesson. The software was also found to improve learners' reading and listening skills in English.
\end{abstract}

Index Terms-Game based learning, siLang, case study, ICT, software

\section{INTRODUCTION}

Literacy in Information and Communication Technologies (ICT) is considered fundamental to life in the contemporary modern technological society. Meanwhile, in the World market and the business, scientific and technological reality of today, English is indispensable for both job qualifications and successful task implementation. Especially today, English is thought to be a prerequisite for both academic and professional purposes. Therefore, students need to be trained accordingly and teachers need to be informed on the latest methods and teaching strategies. Based on the aforementioned ascertainments and the educational and professional demands of today, teachers' training in the use of new technologies seems all the more necessary in all disciplines. Thus, tools such internet or educational software for instance, have become important tools in their hands for creative lesson planning, student motivation, student participation increase and successful teaching processes. This particular need has led to English language learning and teaching for Specific Purposes (E.S.P.), a term that refers to linguistic programs, designed especially for groups or individuals with a specific purpose to learn English, which in the long term will meet with the learners' E.S.P. linguistic needs [1]. Consequently, to equip learners to be literate lifelong learners and global citizens of the $21^{\text {st }}$ century we must integrate ICT into both the English curriculum and English pedagogical practice [2].

Research findings reveal that Information and Communications Technology plays an important role in enabling teachers and students of languages to communicate with one another across the globe. ICT is a valuable tool to enhance teaching and learning. More specifically, for teachers, ICT is a professional resource, a mode of classroom delivery while for learners ICT provides opportunities to communicate more effectively and to develop all four skills (reading, writing, speaking and listening). Because of its interactive and dynamic nature, ICT has the potential to meet the needs of individual students by providing opportunities to direct their learning and to pursue information or complete tasks, in ways which meet their own interests and needs [3]. Moreover, the use of ICT tools promotes interactive lessons and strongly encourages e-learning among pupils to speed up the teaching and learning of English [4]. As well, the use of ICTs was found to be positively and significantly related to teachers' successful teaching practices, as concerns listening, speaking and pronunciation activities [5].

On the whole, the entry of new technologies into our lives over the last decades of the 21 st century has radically changed our daily routine and modes of communication in many aspects. New technological achievements have emerged and have created a new era, the so-called digital society and information. This new challenge has also affected education introducing new multifaceted applications and innovative ideas mainly based on interaction, cooperation and communication. E-learning is a fact and new environments have appeared; the internet, multimedia, and educational software are replacing the traditional classroom and the traditional teacher-centered teaching methods. Education is now suggested to be studentcentered and knowledge is provided to the student by the teacher whose role has changed; $\mathrm{He}$ is no longer the carrier of new knowledge but the supporter and facilitator of students whose basic tasks are to learn how to learn, an essential and irreplaceable skill for life.

In this new era of technology and information, schools should give students the opportunity for knowledge through the exploitation of the available technological applications for the purposes of learning and skills development. Teaching tools, such educational software enhance learners' communicative abilities and collaborative learning, improving teaching practices and facilitating learning. Educational software can contribute to this objective as they have been found to be modern teaching tools for teaching, learning and communication $[6,7,8,9,10]$. They are environments that comprise teaching objectives, integrate scenarios with educational value and mainly produce specific teaching and learning outcomes. Their use can enhance learning by encouraging students' active participation, focusing on skills acquisition, exploiting the opportunities they offer for interdisci- 
PAPER

The siLAng Simulation ToOl for Business SeCONDARY TECHNICAl EdUCATION E.S.P. STUdENTS

plinary and interactive simulations of real life tasks $[11,12,13]$.

Electronic games and educational software are environments that encourage students to be active in class, offering them a pleasant virtual world, interacting either individually or in collaboration with other students. They are motivating, and enhance learners' participation in activities which promote imagination and creativity. They encourage learners' intrinsic motives, leading to an effort of successful implementation of tasks without demanding any reward [14].

Based on feelings of control, curiosity and imagination, extrinsic and intrinsic motivation, students participate in activities within the context of an educational digital activity [15]. Educational computer games especially encourage the development of logic, skills acquisition and knowledge transfer in a pleasant way, [16] as users implement the tasks given in order to achieve the objectives proposed. Ever since the very first research conducted on the field of using games in education [17] there has been proof of the educational games and software as being sources of motivation for users to test their knowledge, and develop their skills by applying knowledge to learn things that did not know, enjoying themselves at the same time [18]. Additionally, the use of multimedia in the creation of attractive stories that present real or imaginary goals increase the learning achievement, as they offer learners an incentive to continue playing, and provide them with immediate feedback, and the ability to test various skills and strategies[19].

Teachers' main concern is the suitability of available teaching tools in the educational process, and in this case of educational software. Although the value of software as a learning process means positive results in learning, especially because they can be adaptive and personalized to each student, their suitability depends on many factors. Some of them are age, level and interests of students, clarity of instructive objectives, offer of possibilities for active learning and problem solving as well as their integration into the school program $[20,21,22,23]$. Above all it is their endorsement as learning tools by the beneficiaries themselves, ie students who use it.

Research shows that students are an important source of information regarding the suitability of software, since it is those who use the software in the school laboratory. Moreover, it appears that students' participation may be the best method of recording the positive/negative aspects of software, since students are the ultimate users and therefore the main judges. Thus, students who have direct contact with educational software are able to submit their opinion regarding the appropriateness of educational software.

\section{Rationale For The Present StUdy}

Education is quite a complex situation and it needs a lot of effort on behalf of teachers and authorities to produce effective results. Students of today are not the passive learners of the past but the active participants of a new digital era, in which many a time they even precede their own teachers in ICT skills. It is quite a challenge for which educators need to prepare accordingly to meet with their learners' level and needs. For, education is not and should not be a dull process but an engaging, active, participative and interesting one. In simple words, learning is not about memorizing but about discovering knowledge, training in new skills and finding meaning in learning. It is a process in which learners need to respond actively, to interact, to engage in the learning process and experience real life situations so as to successfully prepare themselves for their future social, academic and professional needs.

Technical Vocational school learners need to prepare appropriately for their future vocational demands. What is more, many times, traditional school books are not always based on contemporary working environments, thus, failing to offer learners with updated information and knowledge, as very often, they include boring nonauthentic tasks which learners find no meaning for. Based on the educational value of the software, as shown at the literature review and the aforementioned problems at Vocational schools, the authors of this paper decided to motivate learners by introducing them to "siLang", a game based virtual environment and the simulation of realbusiness settings aiming, one: to draw their views on the appropriateness of the software and two: investigate the extent to which its use can improve learners' receptive skills in English (reading and listening). SiLang is a free application and it introduces situated learning tasks in order to develop learners' skills and familiarize them with "specific work-related situations in varying cultures" (http://www.si-lang.net). It simulates business like environments and related situations, offering learners a reallike aspect of business settings and transactions. It also "aims to develop serious gaming approaches for building language and cultural competencies on the use of vehicular languages in the world of work by professionals, vocational workers, academics, and students" (http://www.silang.net).

\section{THE RESEARCH}

\section{A. Research questions}

Conducting the research with both a quantitative and qualitative method the research questions were as follows: 1. To what extent has "siLang" improved learners' reading business skills competence in the English language? 2. To what extent has "siLang" improved learners' listening business skills competence in the English language? 3. What do learners think of "siLang" as a teaching tool?

\section{B. The Sample}

The research took place in the Fall of 2014. Sixty four Vocational School learners participated in the research aged 16-17. They all came from three different classes attending the specialty of the Vocational business sector. Their official level in English is set by the state to be that of B1, according to the Common European Framework of Languages. In addition to the learners, their teachers participated in the research (three women and a man).

\section{Research tools}

Learners' skill competence was measured with the use of the National Foreign Language Exam System (KPG test), which comprises four modules (reading comprehension and language awareness, writing and written mediation, listening comprehension, speaking and oral mediation). KPG is a stabilized test, used to assess learners' skills competence in foreign languages. The maximum possible score at B1 level candidates can gain is 100 . The pass mark for the KPG, as set by law, is 60 . Candidates 
must gain at least $30 \%$ of the maximum possible marks in Modules 1-3; there is no minimum mark required in Module 4, although the marks candidates receive are included in their total score. The test, and particularly its reading and listening parts, were used to provide the researchers with answers for the first two questions. For the third question a focus group with randomly selected learners was formed, asking learners' opinion on the specific tool (table 1).

TABLE I.

KPG EXAM SPECIFICATIONS

\begin{tabular}{|c|c|c|c|c|c|c|c|}
\hline \multirow{2}{*}{$\begin{array}{c}\text { Mod- } \\
\text { ule }\end{array}$} & \multirow{2}{*}{$\begin{array}{c}\text { Type of } \\
\text { items/tasks }\end{array}$} & \multirow{2}{*}{$\begin{array}{c}\text { Number } \\
\text { of } \\
\text { items/tas } \\
\text { ks }\end{array}$} & \multirow[b]{2}{*}{$\begin{array}{c}\text { Weigh } \\
\text { ting }\end{array}$} & \multicolumn{2}{|c|}{ Mark } & \multirow{2}{*}{$\begin{array}{l}\text { Time } \\
\text { (min } \\
\text { utes) }\end{array}$} & \multirow[b]{2}{*}{$\begin{array}{l}\text { Text size } \\
\text { (words) }\end{array}$} \\
\hline & & & & $\operatorname{Max}$ & Min & & \\
\hline \multirow{2}{*}{1} & Choice & 40 & 0.5 & 20 & \multirow[b]{2}{*}{0} & \multirow{2}{*}{65} & \multirow{2}{*}{$\begin{array}{l}700- \\
1000\end{array}$} \\
\hline & Completion & 10 & 0.5 & 5 & & & \\
\hline 2 & $\begin{array}{l}\text { Semi guided } \\
\text { written } \\
\text { production }\end{array}$ & $2-3$ & - & 30 & 9 & 45 & $160-200$ \\
\hline \multirow{2}{*}{3} & Choice & 15 & 1 & 15 & \multirow{2}{*}{8} & \multirow{2}{*}{$15-20$} & \multirow{2}{*}{$\begin{array}{c}\text { Not } \\
\text { defined }\end{array}$} \\
\hline & Completion & 5 & 2 & 10 & & & \\
\hline 4 & $\begin{array}{l}\text { Semi guided } \\
\text { oral produc- } \\
\text { tion }\end{array}$ & 3 & - & 20 & - & $15-20$ & $\begin{array}{c}\text { Not } \\
\text { defined }\end{array}$ \\
\hline \multicolumn{4}{|c|}{$\begin{array}{l}\text { Minimum total grade required for B1 } \\
\text { level certification }\end{array}$} & & 60 & & \\
\hline \multicolumn{4}{|c|}{$\begin{array}{l}\text { Highest possible grade for B1 level } \\
\text { certification }\end{array}$} & 100 & & & \\
\hline
\end{tabular}

For the purposes of the third question however learners also answered a questionnaire regarding their views on 'SiLang'. The questionnaire comprised 8 questions with answers given on a five point Likert scale of 'very much', 'a lot', 'quite', 'a little' and 'not at all'. The questions were designed to draw learners' opinion regarding: relevance of content to business English language material, ability to enhance English language skills acquisition, its relevance to future working needs, the extent to which it is contemporary and updated, its ability to encourage active participation, its ability to present realistic simulated situations, easiness of use, interactivity between user and tasks. For the interviews with the teachers, semi constructed questions were also used to detect their opinion on the software. The data from a pilot study conducted with a teacher for the validity of the research tool were used in order to reformulate a number of questions. The interviews took place outside the school premises, in the afternoon, in a nearby library. All teachers were reassured that they could withdraw any time they felt uncomfortable and were explained they could receive a copy of the interview transcription. The questions of the interview were classified in two categories: 1. Working profile of the participants 2. The teachers' views on the effectiveness of the siLang software.

\section{Research stages}

The study, which lasted for eight weeks took place in six successive phases:

$1^{\text {st }}$ phase (2 hours): As a first step, three Vocational school classes were randomly selected in the research location, in September 2014. The next step was first to ask and finally receive the state permission in order to conduct the research and then the principal's and the parents' consent.

$2^{\text {nd }}$ phase (2 hours): This stage comprised the participation of all learners in a pre-reading and listening KPG test to detect their level in English. The test was taken the same day by the participant groups.

$3^{\text {rd }}$ phase (2 hours): The teachers explained the basic steps of SiLang giving examples regarding the interface and its use.

$4^{\text {th }}$ phase ( 8 hours): This phase of the research was conducted in a series of eight lessons where the students implemented the tasks followed. With the help of their teachers, learners worked on the software based on thematic areas of their business syllabus and relevant curriculum. The case study was based on a project about 'Looking for a job - business transactions' and learners had to work on the tasks given.

$5^{\text {th }}$ phase (2 hours): By the end of the intervention, learners took a post KPG reading and listening test to detect the level of improvement. The test did not have the same tasks but similar ones and level as the previous one. The test was taken the same day or the following by all students, who answered it with exactly the same time allocated by the test specifications. They also took a questionnaire and participated in a focus group discussion.

$6^{\text {th }}$ phase: In this stage, learners took a similar follow up test, again of the same level to determine any differentiation in their answers. This was done three weeks after their second test (post-test).

\section{DATA ANALYSIS}

\section{A. Method of processing the experimental data}

Analysis of the overall data collected followed. In addition to the multiple choice questions of the questionnaire, content analysis was performed on the interview data, something that also happened for the open-type questions, which ended-up being classified into broad categories, for the purpose of being used in a form of quantitative data, and to extract any real information contained in them.

\section{B. Statistical analysis-data analysis}

For the checking of statistical hypotheses we use the aforementioned SPSS statistical package. The checking of the statistical hypotheses aims at verifying or rejecting a hypothesis. In order to exploit the sample data we formulate two hypotheses: a) null hypothesis Ho which is based on the acceptance that there is not a statistical significant effect of the independent sample on the dependent and b) alternative hypothesis $\mathrm{H} 1$ which expresses the opposite of the null. A statistically significant difference, smaller than an acceptable limit of significance $(5 \%, 1 \%$ or $1 \%$ ) means the rejection of the null hypothesis and the acceptance of the null $[1,2]$. In the present research we set the level of significance at $5 \%$. The use of the appropriate checking criterion (parametric or not) of the research hypothesis depends mainly on the plan of the research, the commitment of the level of the data and the type of the indexes of the measurement of the variables.

In this research the appropriate statistical criterion is the parametric $t$ criterion for depended samples that fulfil the conditions of its use. The research hypotheses are: 
Ho: Null hypothesis: Students' performance remained the same after the teaching intervention

H1: Alternative hypothesis: Students' performance did not remain the same after the teaching intervention

It should be noted that there is no attempt to predict which group displays the best or worse performance. Therefore a two-sided checking hypothesis is formulated. The results of the SPSS statistical package are presented below.

\section{Data analysis methodology}

The results of the statistical analysis with the use of SPSS statistical package are given on the following table of descriptive statistics:

TABLE II.

MEAN PRE QUESTION

Descriptive Statistics

\begin{tabular}{|l|c|c|c|}
\hline \multicolumn{1}{|c|}{ N } & \multicolumn{2}{|c|}{ Mean } \\
\cline { 2 - 4 } & Statistic & Statistic & Std. Error \\
\hline $\begin{array}{l}\text { Q1. Is the content of the educa- } \\
\text { tional software relevant to your } \\
\text { business English language mate- }\end{array}$ & 64 & 4,36 &, 112 \\
rial? & & & \\
Q2. Is the tool attractive? & 64 & 3,98 &, 129 \\
$\begin{array}{l}\text { Q3. Is it appropriate for your } \\
\text { age? }\end{array}$ & 64 & 3,67 &, 153 \\
Q4. Does it have an interesting \\
$\begin{array}{l}\text { source of images? } \\
\text { Q5. Is it innovative in its de- } \\
\text { sign? }\end{array}$ & 64 & 4,39 &, 115 \\
$\begin{array}{l}\text { Q6. Is it appropriate for learning } \\
\text { purposes? }\end{array}$ & 64 & 3,98 &, 115 \\
$\begin{array}{l}\text { Q7.Give reasons as to why (if at } \\
\text { all) you think the tool is can } \\
\text { help you with your lessons- } \\
\text { Promotes students' interest } \\
\text { Q8.Give reasons as to why (if at } \\
\text { all) you think the tool is can } \\
\text { help you with your lessons- }\end{array}$ & 64 & 3,19 &, 128 \\
$\begin{array}{l}\text { Promotes active participation } \\
\text { Valid N (listwise) }\end{array}$ & 64 & 3,95 &, 139 \\
\hline
\end{tabular}

The following chart presents the average with the error bars per question:

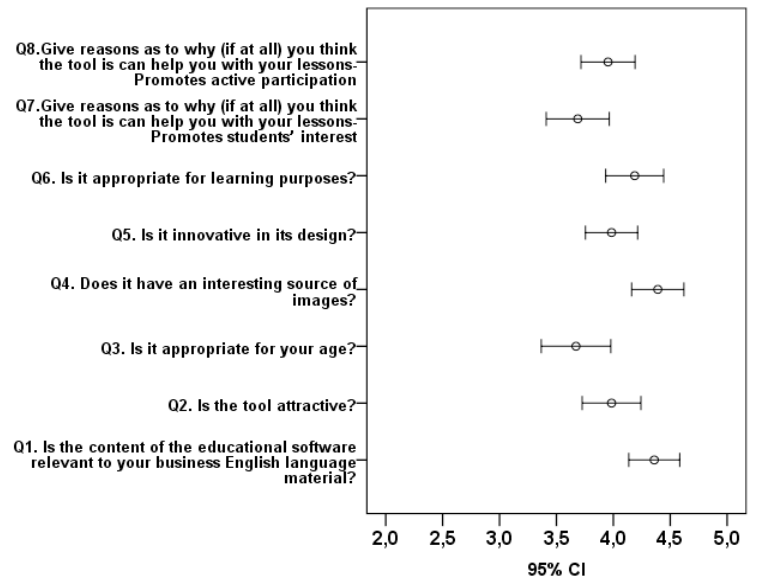

Figure 1. Error chart per question

Analytically, we have the following per question:
1. Question 1: Is the content of the educational software relevant to your business English language material?

Students' answers are recorded on the following table of descriptive statistics as they resulted from the SPSS analysis:

TABLE III.

Q1. Is THE CONTENT OF THE EDUCATIONAL SOFTWARE RELEVANT TO YOUR BUSINESS ENGLISH LANGUAGE MATERIAL?

\begin{tabular}{|cl|c|c|c|}
\hline & Frequency & $\begin{array}{c}\text { Valid } \\
\text { Percent }\end{array}$ & $\begin{array}{c}\text { Cumulative } \\
\text { Percent }\end{array}$ \\
\hline \multirow{2}{*}{ Valid } & not at All & 1 & 1,6 & 1,6 \\
& a Little & 3 & 4,7 & 6,3 \\
Quite & 3 & 4,7 & 10,9 \\
a Lot & 22 & 34,4 & 45,3 \\
Very Much & 35 & 54,7 & 100,0 \\
Total & 64 & 100,0 & \\
\hline
\end{tabular}

Based on the above table and the general table I we can see that a large percentage of students consider that the SiLang software is relevant to the business language material "Very Much" $54,7 \%$ or "a lot" on the test scale, that is, $34,4 \%$.

The answers to the specific question are also shown on the following frequency diagram:

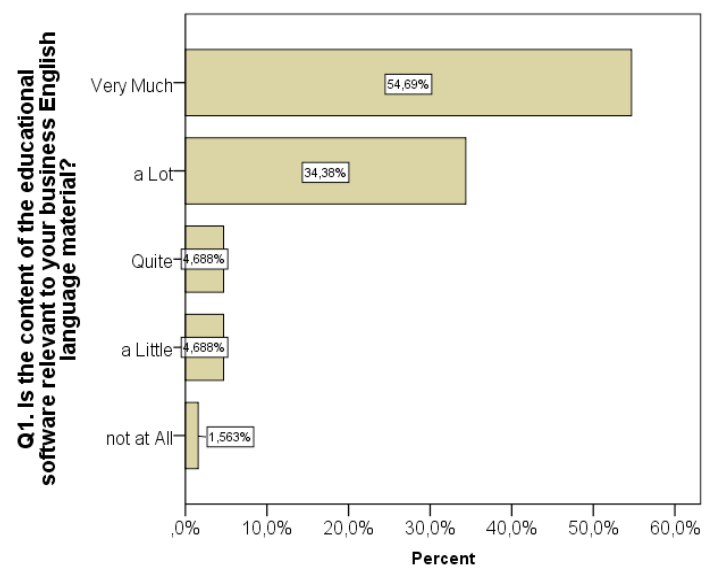

Figure 2. Is the content of the educational software relevant to your business English language material?

2. Question 2: Does the content of the software complement and enhance your English language skills knowledge?

Students' answers are recorded on the following table of descriptive statistics as they resulted from the SPSS analysis:

TABLE IV.

Q2. DOES THE CONTENT OF THE SOFTWARE COMPLEMENT AND ENHANCE YOUR ENGLISH LANGUAGE SKILLS KNOWLEDGE?

\begin{tabular}{|cl|c|c|c|}
\hline & Frequency & $\begin{array}{c}\text { Valid } \\
\text { Percent }\end{array}$ & $\begin{array}{c}\text { Cumulative } \\
\text { Percent }\end{array}$ \\
\hline Valid & not at All & 2 & 3,1 & 3,1 \\
& a Little & 5 & 7,8 & 10,9 \\
Quite & 7 & 10,9 & 21,9 \\
a Lot & 28 & 43,8 & 65,6 \\
Very Much & 22 & 34,4 & 100,0 \\
Total & 64 & 100,0 & \\
\hline
\end{tabular}


Based on the above table and the general table I we can see that a large percentage of students consider that the SiLang software complements and enhances the English language skills "Very Much" $34,4 \%$ or "a lot" on the test scale, that is, $43,8 \%$.

The answers to the specific question are also shown on the following frequency diagram:

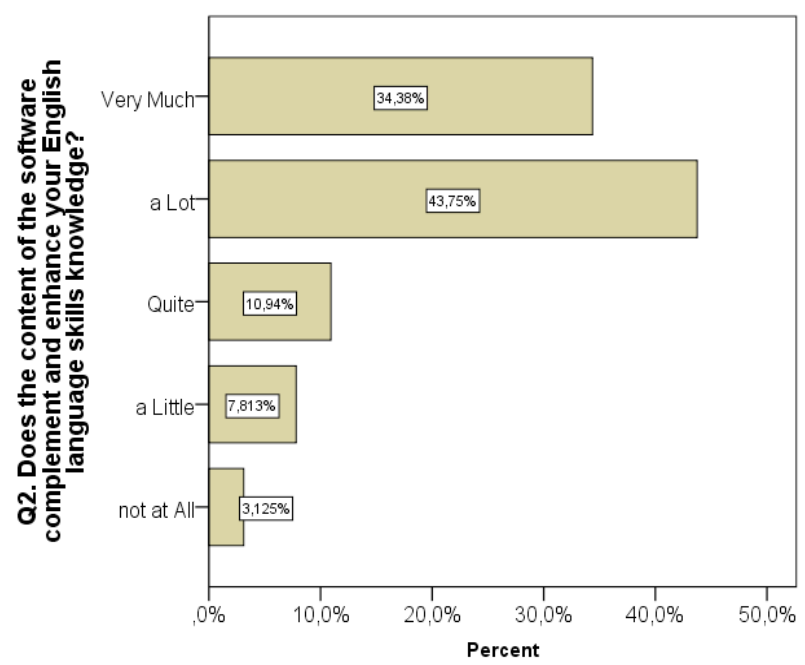

Figure 3. Does the content of the software complement and enhance your English language skills knowledge?

\section{Question 3: Is the content of the software relevant to} your future linguistic working needs?

Students' answers are recorded on the following table of descriptive statistics as they resulted from the SPSS analysis:

TABLE V.

Q3. Is The Content Of The SOFtward Relevant To Your Future LINGUISTIC WORKING NEEDS?

\begin{tabular}{|cl|c|c|c|c|}
\hline & Frequency & Percent & $\begin{array}{c}\text { Valid } \\
\text { Percent }\end{array}$ & $\begin{array}{c}\text { Cumulative } \\
\text { Percent }\end{array}$ \\
\hline Valid & not at All & 4 & 2,5 & 6,3 & 6,3 \\
& a Little & 9 & 5,6 & 14,1 & 20,3 \\
Quite & 10 & 6,2 & 15,6 & 35,9 \\
a Lot & 22 & 13,7 & 34,4 & 70,3 \\
Very Much & 19 & 11,8 & 29,7 & 100,0 \\
Total & 64 & 39,8 & 100,0 & \\
\hline
\end{tabular}

Based on the above table and the general table I we can see that a large percentage of students consider that the SiLang software content is relevant to learners' future linguistic working needs " a Lot" $34,4 \%$ or "Very Much" on the test scale, that is, $29,7 \%$.

The answers to the specific question are also shown on the following frequency diagram:

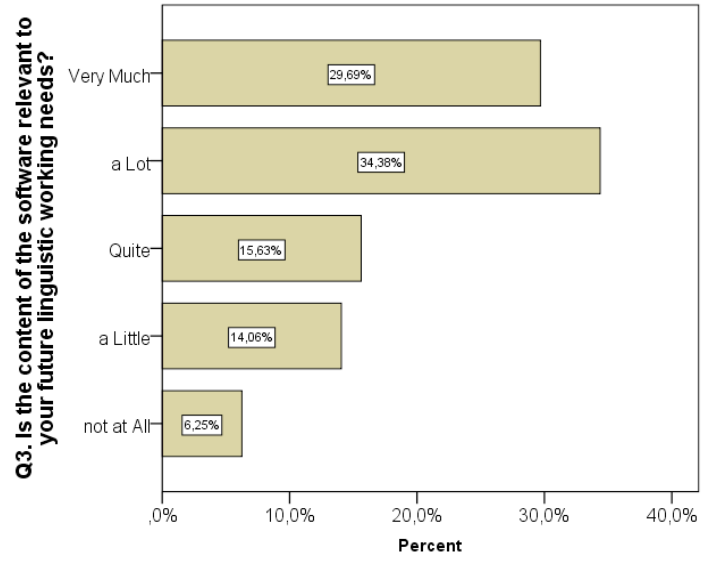

Figure 4. Is the content of the software relevant to your future linguistic working needs?

4. Question 4: Is the information provided in the software contemporary and updated according to the latest business setting environments you are introduced in your lessons?

Students' answers are recorded on the following table of descriptive statistics as they resulted from the SPSS analysis:

TABLE VI.

Q4. IS THE INFORMATION PROVIDED IN THE SOFTWARE CONTEMPORARY AND UPDATED ACCORDING TO THE LATEST BUSINESS SETTING ENVIRONMENTS YOU ARE INTRODUCED IN YOUR LESSONS?

\begin{tabular}{|cl|c|c|c|}
\hline & Frequency & $\begin{array}{c}\text { Valid } \\
\text { Percent }\end{array}$ & $\begin{array}{c}\text { Cumulative } \\
\text { Percent }\end{array}$ \\
\hline \multirow{2}{*}{ Valid } & not at All & 1 & 1,6 & 1,6 \\
& a Little & 3 & 4,7 & 6,3 \\
& Quite & 4 & 6,3 & 12,5 \\
a Lot & 18 & 28,1 & 40,6 \\
Very Much & 38 & 59,4 & 100,0 \\
Total & 64 & 100,0 & \\
\hline
\end{tabular}

Based on the above table and the general table I we can see that a large percentage of students consider that the SiLang software is contemporary and updated "Very Much" 59,4\% or "a Lot" on the test scale, that is, $28,1 \%$.

The answers to the specific question are also shown on the following frequency diagram:

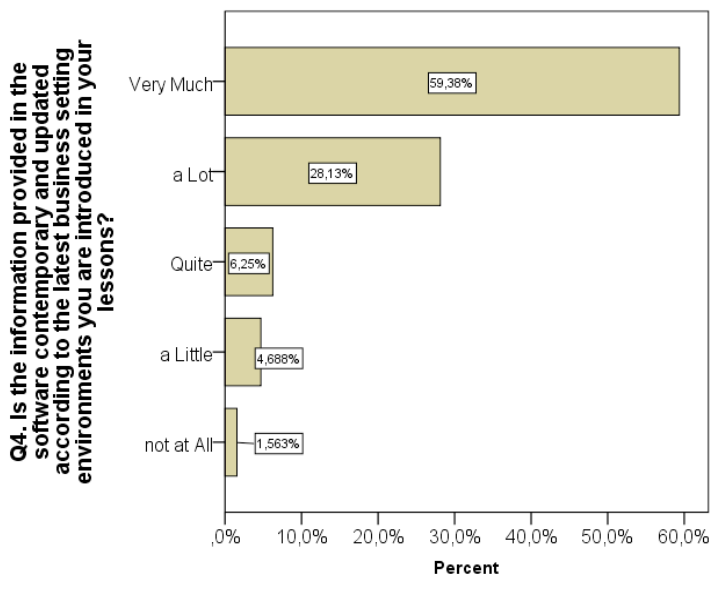

Figure 5. Is the information provided in the software contemporary and updated according to the latest business setting environments you are introduced in your lessons? 
Question 5: Does the software encourage students' active participation?

Students' answers are recorded on the following table of descriptive statistics as they resulted from the SPSS analysis:

TABLE VII.

Q5. DOES THE SOFTWARE ENCOURAGE STUDENTS' ACTIVE PARTICIPATION?

\begin{tabular}{|cl|c|c|c|}
\hline & Frequency & $\begin{array}{c}\text { Valid } \\
\text { Percent }\end{array}$ & $\begin{array}{c}\text { Cumulative } \\
\text { Percent }\end{array}$ \\
\hline Valid & not at All & 1 & 1,6 & 1,6 \\
& a Little & 3 & 4,7 & 6,3 \\
Quite & 12 & 18,8 & 25,0 \\
a Lot & 28 & 43,8 & 68,8 \\
Very Much & 20 & 31,3 & 100,0 \\
Total & 64 & 100,0 & \\
\hline
\end{tabular}

Based on the above table and the general table I we can see that a large percentage of students consider that the SiLang software encourages students' active participation "a Lot" $43,8 \%$ or "Very Much" on the test scale, that is, $31,3 \%$.

The answers to the specific question are also shown on the following frequency diagram:

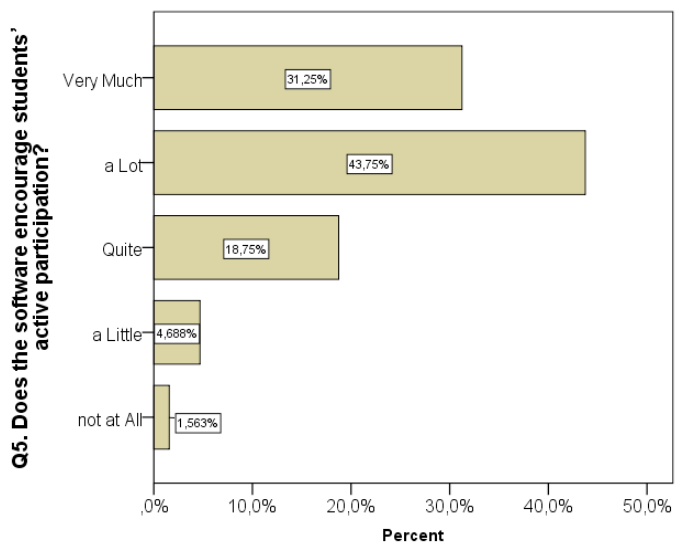

Figure 6. Does the software encourage students' active participation?

\section{Question 6: Are the presented simulated situations realistic?}

Students' answers are recorded on the following table of descriptive statistics as they resulted from the SPSS analysis:

TABLE VIII.

Q6. ARE THE PRESENTED SIMULATED SITUATIONS REALISTIC?

\begin{tabular}{|cl|c|c|c|}
\hline & Frequency & $\begin{array}{c}\text { Valid } \\
\text { Percent }\end{array}$ & $\begin{array}{c}\text { Cumulative } \\
\text { Percent }\end{array}$ \\
\hline Valid & not at All & 1 & 1,6 & 1,6 \\
& a Little & 4 & 6,3 & 7,8 \\
Quite & 10 & 15,6 & 23,4 \\
a Lot & 16 & 25,0 & 48,4 \\
Very Much & 33 & 51,6 & 100,0 \\
Total & 64 & 100,0 & \\
\hline
\end{tabular}

Based on the above table and the general table I we can see that a large percentage of students consider that the SiLang software presents simulated realistic situations
"Very Much" $51,6 \%$ or "a Lot" on the test scale, that is, $25 \%$.

The answers to the specific question are also shown on the following frequency diagram:

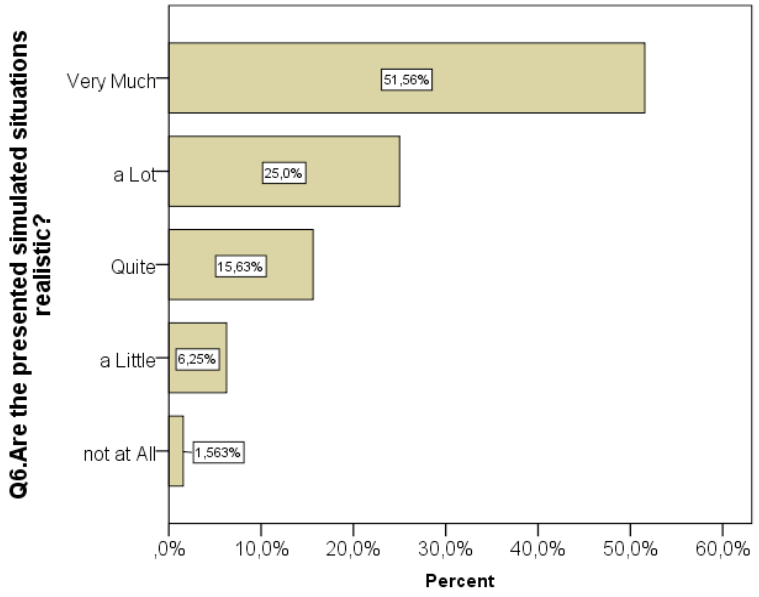

Figure 7. Are the presented simulated situations realistic?

7. Question 7: Are the basic software operations easy to use?

Students' answers are recorded on the following table of descriptive statistics as they resulted from the SPSS analysis:

TABLE IX

Q7. ARE THE BASIC SOFTWARE OPERATIONS EASY TO USE?

\begin{tabular}{|cl|c|c|c|}
\hline & Frequency & $\begin{array}{c}\text { Valid } \\
\text { Percent }\end{array}$ & $\begin{array}{c}\text { Cumulative } \\
\text { Percent }\end{array}$ \\
\hline \multirow{2}{*}{ Valid } & not at All & 3 & 4,7 & 4,7 \\
& a Little & 5 & 7,8 & 12,5 \\
& Quite & 19 & 29,7 & 42,2 \\
a Lot & 19 & 29,7 & 71,9 \\
Very Much & 18 & 28,1 & 100,0 \\
Total & 64 & 100,0 & \\
\hline
\end{tabular}

Based on the above table and the general table I we can see that a large percentage of students consider that the SiLang software operations are easy to use "Quite" $29,7 \%$ or "a Lot" on the test scale, that is, $29,7 \%$.

The answers to the specific question are also shown on the following frequency diagram:

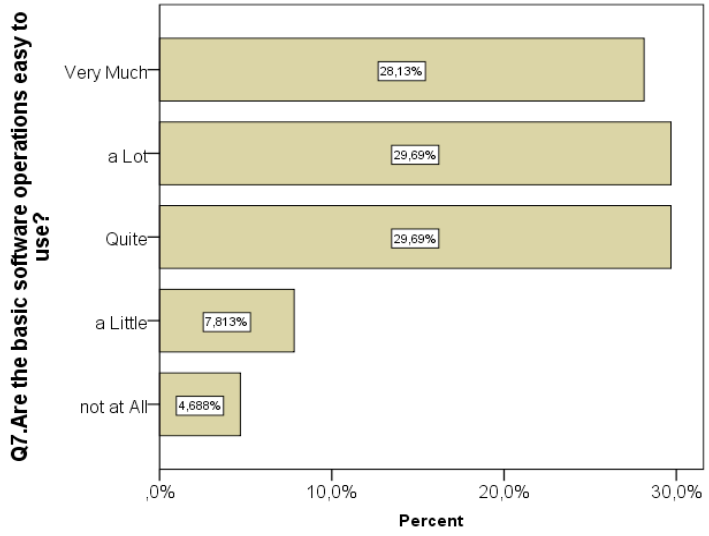

Figure 8. Are the basic software operations easy to use? 
8. Question 8: Is there a possibility of interaction between the user and the simulated situations?

Students' answers are recorded on the following table of descriptive statistics as they resulted from the SPSS analysis:

TABLE X.

Q8. IS THERE A POSSIBILITY OF INTERACTION BETWEEN THE USER AND THE SIMULATED SITUATIONS?

\begin{tabular}{|cl|c|c|c|c|}
\hline & Frequency & Percent & $\begin{array}{c}\text { Valid } \\
\text { Percent }\end{array}$ & $\begin{array}{c}\text { Cumulative } \\
\text { Percent }\end{array}$ \\
\hline Valid & not at All & 5 & 3,1 & 7,8 & 7,8 \\
& a Little & 15 & 9,3 & 23,4 & 31,3 \\
Quite & 22 & 13,7 & 34,4 & 65,6 \\
a Lot & 22 & 13,7 & 34,4 & 100,0 \\
Very Much & 64 & 39,8 & 100,0 & \\
Total & 5 & 3,1 & 7,8 & 7,8 \\
\hline
\end{tabular}

Based on the above table and the general table I we can see that a large percentage of students consider that the SiLang software presents a possibility of interaction "Very Much" $34,4 \%$ or "a Lot" on the test scale, that is, $34,4 \%$.

The answers to the specific question are also shown on the following frequency diagram:

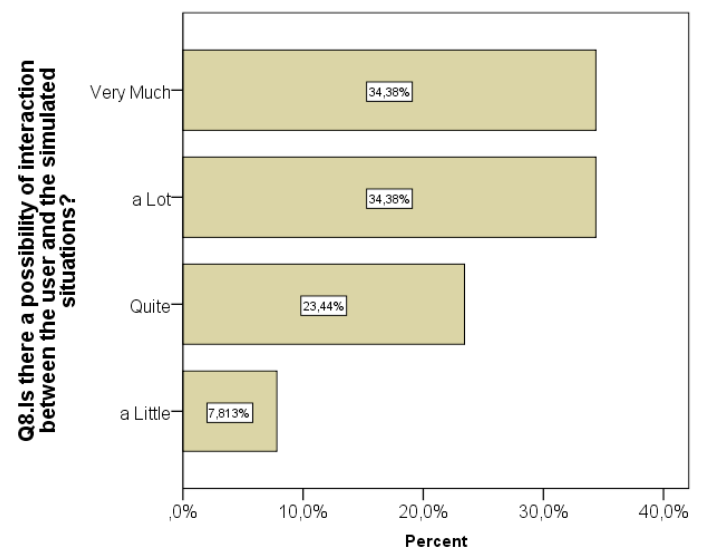

Figure 9. Is there a possibility of interaction between the user and the simulated situations?

\section{Checking the effectiveness of the instructive tool in the pre/post-testing}

With the use of the SPSS statistical package and the ttest statistical criterion of independent samples we have the following (table XI).

Based on $t$ criterion and the data from the above table for all possible comparisons at pre and post-test the result is statistically significant $(\mathrm{p}<0,05)$ and leads to the acceptance of the alternative hypothesis, that is learners' performance in all instructive aims of Reading and Listening has improved significantly after the teaching intervention $(\mu o \neq \mu 1)$. Based on the above table we can see that there is an improvement for reading at a $20,23 \%( \pm 9,13 \%)$ and an improvement for listening at a $14,59 \%( \pm 8,44 \%)$ at the post test compared to the pre-test performance.
TABLE XI.

RESUlts OF THE T CRITERION FOR DEPENDED SAMPLES At PRE/POST TESTING

Paired Sample Correlations

\begin{tabular}{|c|c|c|c|c|c|}
\hline & & Mean & $\mathbf{N}$ & $\begin{array}{c}\text { Std. } \\
\text { Deviation }\end{array}$ & $\begin{array}{l}\text { Std. } \\
\text { Error } \\
\text { Mean }\end{array}$ \\
\hline \multirow[t]{2}{*}{ Pair 1} & $\begin{array}{l}\text { Efficien- } \\
\text { cy_Reating_PreTest }\end{array}$ & $\begin{array}{r}51,0 \\
3\end{array}$ & 64 & 8,20 & 1,02595 \\
\hline & $\begin{array}{l}\text { Efficien- } \\
\text { cy_Reating_PostTest }\end{array}$ & $\begin{array}{r}71,2 \\
6\end{array}$ & 64 & 7,45 & ,93149 \\
\hline \multirow[t]{2}{*}{ Pair 2} & $\begin{array}{l}\text { Efficien- } \\
\text { cy_Listening_PreTes } \\
\mathrm{t}\end{array}$ & $\begin{array}{r}48,0 \\
7\end{array}$ & 64 & 9,03 & 1,12958 \\
\hline & $\begin{array}{l}\text { Efficien- } \\
\text { cy_Listening_PostTe } \\
\text { st }\end{array}$ & $\begin{array}{r}62,6 \\
7\end{array}$ & 64 & 10,18 & 1,27301 \\
\hline
\end{tabular}

Paired Samples Test

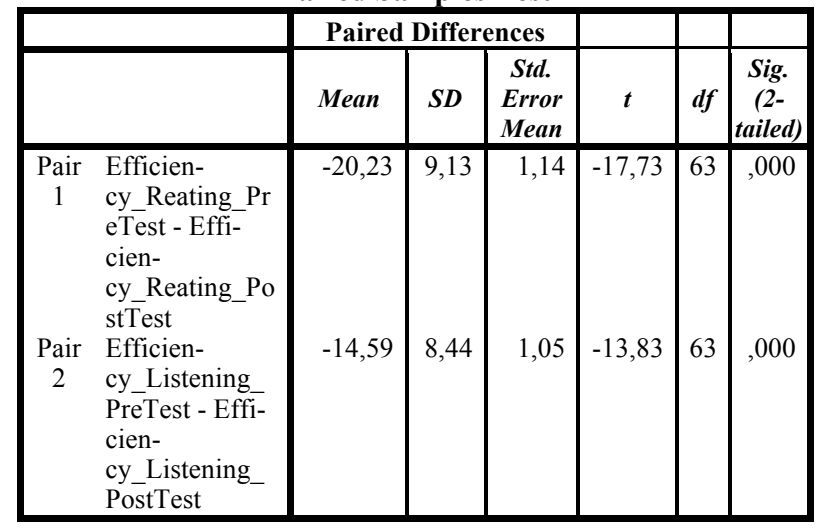

We reach the same conclusion using a chart (error chart 1) with confidence intervals of the averages of the performance for every group.

From the chart in Figure 10 we can support the fact that there is a statistically significant difference between pretest and post-test for comparisons of the groups as there are no corresponding overlaps.

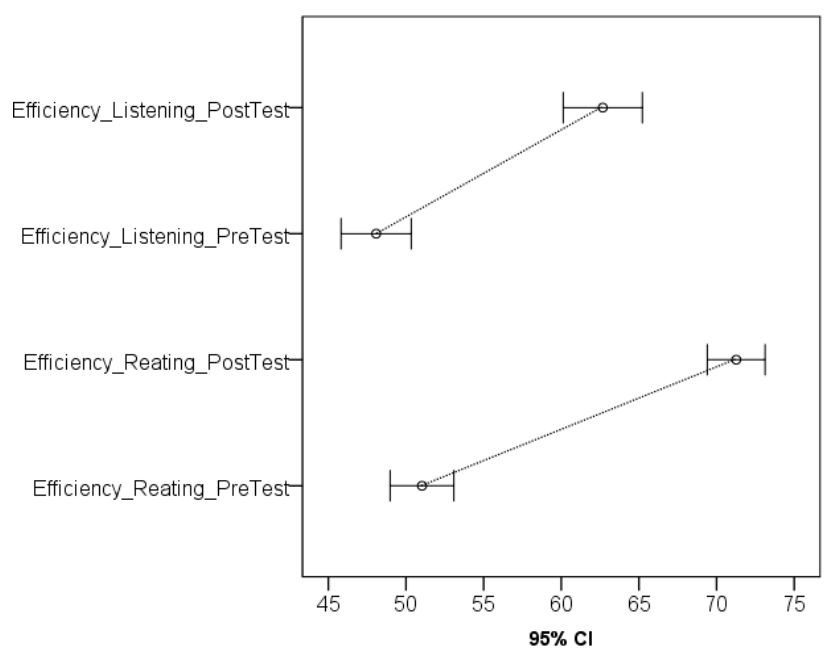

Figure 10. Error chart for the participant groups at pre/post tests 


\section{E. Teachers' Interviews results}

\section{Teachers' working profile}

For validity purposes, the results are accompanied by extracts from the teachers' responses. Meanwhile, for anonymity purposes teachers are referred to as P1, P2, P3 and P4. All teachers worked in this field from 12 to 19 years. They had all been working in Vocational Secondary Schools all those years. However, one of them had also worked for five years in a General Senior High School. They all used ICT in their classes and quite often worked in the school labs with their learners in order to use internet based activities. As the teachers said, this was due to their wish to offer learners authentic material "The book is not enough... especially this old one we have..." $\mathrm{P} 2$, "Twice a month I try to take them to the lab... we use the internet to see real life business places... offices..., equipment... what they will need in work usually... "P3.

\section{Teachers' views on the effectiveness of the software}

Based on the teachers' answers, siLang was found to be a contemporary business settings simulating tool, and useful for learners' working knowledge. As they claimed, the authentic-like material gave learners a clear idea of what a business environment is like "This is how a firm works... students need to see this... see the real business world... "P2. According to the teachers, this very fact motivated the learners to such an extent that activated them and engaged them in the lesson, thus, helping them improve their English language skills and especially listening "If it [the software] can help them improve their skills and understand English better it's fine by me, I'm happy enough with this... they are too, I'm sure of it... "P4. This was due to the fact that the software provided them with a lot of listening input with the relevant activities. They found this very important for learners' future working needs and believed that the interesting interface and variety of the heroes' accents can prepare learners for the real world "All the bright colours and the happy figures... they liked them... it's something they want to see.. this old-fashioned book with cartoons I don't think it gives much to them..."P1 Most importantly however, they stressed learners' change of attitude towards English and skills training "I don't like a naughty class. I want students to like what they do, they are quieter this way. I think this [siLang] has given them something real and interesting to do. And they liked it. They did it. All... to the end [the activities]" P3.

\section{Discussion AND CONCLUSIONS}

In this paper we described an investigating process regarding the use of the 'siLang' software. The results of the research revealed an improvement on learners' receptive skills. The students' questionnaires showed that they found "siLang" interesting, motivating, pleasant, relevant to their studies, with an authentic like and modern business like environment. The note-taking data, during the implementation of the teaching process, together with the focus group data, analysed with the content analysis method, revealed learners' excitement and enthusiasm regarding the specific game and its environment. According to the learners, "siLang" gave them the opportunity to experience what a real business setting looks like, and minimized their fear for the unknown. Moreover, they enjoyed the multicultural aspect of the game and stressed the fact that it introduced them to a world very similar to the one they will probably have to encounter upon graduation. It's worth mentioning that, and as their teachers stressed, never before had they been so active and energetic in their lessons as during the specific intervention. Last, learners revealed that it was the interactive feature of "siLang" that impressed them the most and expressed their wish to be taught with such tools in the future. However, it should be noted here that it is important for teachers to carefully design the activities proposed, so as to have the best educational benefits and avoid the use of such games only for recreational purposes.

Teaching and learning seem to be a great challenge and a difficult task for almost the majority of the teachers who desperately and restlessly seek for ways to improve their methods and approaches. ICT and their latest applications have a lot to offer to assist this difficult task offering a vast source of ideas and tools. Games based learning is an uprising technique and if it is carefully planned and based on instructive scenarios can prove to be a valuable tool in the hands of the teachers for the benefit of learners and education in general. We would like to point out that this was a first attempt to investigate the appropriateness of this tool. As a next step we intend to conduct a comparative study between the use of the software and the traditional method of teaching (book centred) in order to have a clearer and more detailed view regarding the specific environment and its educational value.

\section{REFERENCES}

[1] T. Hutchison and A. Waters, English for Specific Purposes: A Learning Centered Approach. Cambridge: Cambridge University Press, 1987. http://dx.doi.org/10.1017/CBO9780511733031

[2] D. Crystal, Language and the Internet, Cambridge: Cambridge University Press, 2001. http://dx.doi.org/10.1017/CBO978113 9164771

[3] G. Kress, Literacy in the New Media Age, London: Routledge, 2003. http://dx.doi.org/10.4324/9780203164754

[4] R. J. Samuel, and A. B. Zaitun, "Do Teachers have Adequate ICT Resources and the Right Skills in Integrating ICT Tools in the Teaching and Learning of English Language in Malaysian Schools?" EJISDC (2007), Vol. 29 (2), pp.1-15, 2007.

[5] M. Rahimi, and S, Yadollahi, "ICT Use in EFL Classes: A Focus on EFL Teachers' Characteristics', World Journal of English Language. (October 2011) Vol. 1, (2), pp. 17-29, 2006.

[6] PJ. Burton, and RE Bruhn, 'Using UML to facilitate the teaching of object-oriented systems analysis and design'. Journal of Computing Sciences in Colleges, 19(3):278-290, 2004.

[7] S. Mumtaz, 'Children's enjoyment and perception of computer use in the home and the school', Computers and Education, 36, 347362, 2001. http://dx.doi.org/10.1016/S0360-1315(01)00023-9

[8] S., K. Aliya, The role of computer games in the development of theoretical analysis, flexibility and reflective thinking in children: A longitudinal study, International Journal of Psychophysiology, Vol. 45, 2002.

[9] M., Virvou, G., Katsionis, and K. Manos, 'Combining Software Games with Education: Evaluation of its Educational Effectiveness', Educational Technology \& Society, 8 (2), pp. 54-65, 2005.

[10] D. Squires, 'Educational Software and Learning: Subversive Use and Volatile Design', Proceedings of the $32^{\text {nd }}$ Hawaii International Conference on System Sciences, 1999. http://dx.doi.org/10.1109/hicss.1999.772803

[11] M. Wendy, 'Not Just Tools: the Role of E-technologies in Culture of Learning. Education', Communication \& Information, Vol. 1 (2), pp. 229-235, 2001. http://dx.doi.org/10.1080/14636310126892

[12] S. Vosniadou, 'On the nature of naïve physics'. In M. Limon \& L. Mason (Eds.), Reconsidering conceptual change: Issues in theory 
PAPER

The siLAng Simulation ToOl for Business SeCONDARY TECHNiCAl EdUCATION E.S.P. STUdENTS

and practice, (pp. 61-76) Dordrecht: Kluwer, 2002. http://dx.doi.org/10.1007/0-306-47637-1_3

[13] T. W. Malone, and M. R. Lepper, 'Making Learning Fun: A Taxonomy of Intrinsic Motivations for Learning'. In Snow, R. \& Farr, M., J. (Ed), Aptitude, Learning, and Instruction Volume 3: Conative and Affective Process Analyses. Hillsdale, NJ., 1987.

[14] M. Liu. 'Motivating Students to Learn Using A Game-Based Learning Approach Gaming and Education Issue', Texas Education Review, Vol. 2 (1), pp. 117-128, 2014.

[15] C. Perrotta, G. Featherstone, H. Aston, and E. Houghton, Gamebased Learning: Latest Evidence and Future Directions (NFER Research Programme: Innovation in Education). Slough: NFER, 2013

[16] T. Terzidou, T. Tsiatsos, A. Dae, O. Samaras, and A. Chasanidou, 'Utilizing virtual worlds for game based learning: Grafica, a 3D educational game in Second Life', 12th IEEE International Conference on Advanced Learning Technologies, pp. 624-628, 2012. http://dx.doi.org/10.1109/icalt.2012.55

[17] C. Vrasidas, 'Complexities in the evaluation of distance education and virtual schooling', Educational Media International, Vol. 40 (3), pp. 201-208, 2003. http://dx.doi.org/10.1080/095239803 2000113112

[18] D. Lasagabaster, and J. M. Sierra, 'Student's evaluation of CALL software programs', Educational Media International, Vol. 40 (3), pp. 293-304, 2003. http://dx.doi.org/10.1080/09523980320 00113211

[19] D. Kiegaldie, and G. White, 'The Virtual Patient-Development, Implementation and Evaluation of an Innovative Computer Simulation for Postgraduate Nursing Students', Journal of Educational Multimedia and Hypermedia, Vol. 15 (1), pp. 31-47, 2006.
[20] D. Lasagabaster, and J. M. Sierra, 'Student's evaluation of CALL software programs', Educational Media International, Vol. 40 (3), pp. 293-304, 2003. $\quad$ http://dx.doi.org/10.1080/095239803 2000113211

[21] S. Carsten and J. Niere, 'Thinking in Object Structures: Teaching Modelling in Secondary Schools', Pedagogies and Tools for Learning Object, 2002.

[22] R. Phillips, The Developer's Handbook to Interactive Multimedia: a Practical Guide for Educational Applications. London: Kogan Page, 1997.

[23] A. Korhonen, L. Malmi, P. Myllyselka, and P. Scheinin, 'Does it make a difference if students exercise on the web or in the classroom?' In: Proceedings of The 7th Annual SIGCSE/SIGCUE Conference on Innovation and Technology in Computer Science Education, ITiCSE, Aarhus, Denmark, 2002. http://dx.doi.org/10.1145/544414.544452

\section{AUTHORS}

Ch. Tsihouridis., M.Sc., Ph.D., and Post-Doctoral Research student, Department of Special Education, University of Thessaly, Argonafton \& Filellinon 8221, Volos, Greece (hatsihour@uth.gr).

M. Batsila, M.Sc., M.Ed., and Doctoral Research Student, The Open University, Walton Hall, Milton Keynes, United Kingdom, MK7 6AA (marbatsila@gmail.com)

Submitted 15 December 2015. Published as resubmitted by the authors 03 March 2016. 